\title{
THE EFFECT OF SHORT-TERM STORAGE AND THE HOT WATER TREATMENT OF FRESH-CUT PEPPER FRUIT CV. 'BLONDY F' AND 'YECLA F', ON THE CONTENT OF BIOACTIVE COMPOUNDS AND ANTIOXIDANT PROPERTIES
}

\author{
Justyna I. SZWEJDA-GRZYBOWSKA*, Ryszard KOSSON, Maria GRZEGORZEWSKA \\ Research Institute of Horticulture \\ Konstytucji 3 Maja 1/3, 96-100 Skierniewice, Poland \\ Received: November 2016; Accepted: December 2016
}

\begin{abstract}
The aim of the experiment was to determine the changes in the contents of bioactive compounds and antioxidant/antiradical activity in fresh-cut fruits of sweet pepper cv. 'Blondy $F_{1}$ ' and 'Yecla $F_{1}$ ', depending on the postharvest treatment. Treatment with hot water and short-term storage decreased the content of bioactive compounds and antioxidant/antiradical activity of fruit peppers. The treatment with water at $55{ }^{\circ} \mathrm{C}$ for $12 \mathrm{sec}$. of fresh-cut fruits caused lower losses in content of bioactive compounds and antioxidant/antiradical activities than the treatment with water at $45^{\circ} \mathrm{C}$ for $10 \mathrm{~min}$. There was a significant correlation between the content of total polyphenols and antioxidant and antiradical activity of pepper fruits depending on the cultivar and the experimental season.
\end{abstract}

Key words: pepper, antioxidant activity, antiradical activity, short-term storage, minimal processing

\section{INTRODUCTION}

There is a growing interest among consumers for minimally processed fruit and vegetables - partially or completely prepared for immediate consumption. Technology of minimal processing allows the use of fruits and vegetables in the condition most similar to fresh. One of the important problems limiting the sale of minimally processed vegetables is their poor durability. Due to very limited processing, the biochemical and microbiological processes that occur may lead to disqualification of the product within only a few days of storage because of the sensory changes. In many species of fresh vegetables, including peppers, a decrease in the content of bioactive compounds was observed shortly after fruit harvesting, especially when stored at room temperature (Favell 1998). Another factor contributing to the occurrence of adverse biochemical changes is shredding. It can lead to the destruction of the natural skin barriers, and allows faster multiplication of microorganisms, as well as facilitates the contact of released enzymes with their substrates and accelerates cell respiration (Yildiz 1994). It may also increase the production of ethylene (Varoquaux \& Wiley 1994). In vegetables, a catalyzed oxidation of unsaturated fatty acids by enzymes may occur, leading to the formation of aldehydes and ketones having a significant impact on the flavor of product. In addition, the enzymatic browning reactions, decomposition of chlorophyll and loss of firmness are frequent (Varoquaux \& Wiley 1994). The assessment of microbiological quality of minimally processed vegetables present in our market was the subject of studies of Leszczyńska-Fik and Fik (2003), and Radziejewska-Kubzdela et al. (2007). The above authors did not find the pathogenic bacteria belonging to Salmonella sp. or Listeria sp. in the processed products, but bacteria of the group Coli were present. Leszczyńska-Fik and Fik 2003 suggested that they cannot be indifferent to the health of consumers, 
especially for people with reduced immunity. In order to improve the storage stability of vegetables, treatment with high temperature (about $60{ }^{\circ} \mathrm{C}$ ) was studied. It has been found that this treatment has the influence on lowering rate of respiration, reducing the production of ethylene, delaying ripening, and the reduction of contamination by pathogens of several vegetable species (Lurie 1998; Fallik et al. 1999; Ferguson et al. 2000). Lurie (1998) and Saltveit (1998) found that high temperature favors the formation of Heat Shock Proteins that may contribute to increase of resistance to stresses during storage caused by microorganism infections and physiological disorders (Vlachonasios et al. 2001). Dipping whole pepper fruits for 3 minutes in hot water of $50{ }^{\circ} \mathrm{C}$ reduced their damage by the fungi Botrytis cinerea and Alternaria alternata during storage. Fallik et al. $(1999 ; 2004)$ found that the use of hot water to gently brushing pepper fruit before storage led to increase fruit durability.

The use of new technology for improving the storage stability of sliced vegetables, should contribute to an increase in their range in the market, reducing losses and increasing the consumption of fresh fruit and vegetables.

There is still limited information in the literature about the influence of postharvest treatment on the contents of bioactive compounds, antioxidant and antiradical activity of sweet pepper fruits. Therefore, the aim of the study was to evaluate some consequences of pre-storage hot water treatments of stripped sweet pepper fruit on the content of bioactive compounds and antioxidant activities.

\section{MATERIALS AND METHODS}

Two cultivars of sweet pepper (Capsicum annuum) cvs Blondy $\mathrm{F}_{1}$ (white fruit) and 'Yecla $\mathrm{F}_{1}$ ' (red fruit) were used for the experiment conducted in 2011-2013. The fruits in the stage of consumption ripeness were bought in the company "Agropaprix" in Przystałowice Duże - Kolonia. Immediately after their arrival, they had been washed in water, dried in a stream of air by fans, and then cut into longitudinal strips with a width of $0.5-1.0 \mathrm{~cm}$. One part of each strip was immediately transferred to $5^{\circ} \mathrm{C}$ (Control II), the second was treated with hot water at $45^{\circ} \mathrm{C}$ for $10 \mathrm{~min}$. and the third with water at $55^{\circ} \mathrm{C}$ for $12 \mathrm{sec}$. followed by drying in a stream of air by fan. All strips were packed in PE bags (20 $\times 15 \mathrm{~cm}$ ) with perforations (6 holes $0.04 \mathrm{~cm}$ diameter) and transferred for storage at the temperature $5{ }^{\circ} \mathrm{C}$ for 4 days. Control I was immediately analyzed for chemical properties. The experiment was set in 4 replicates with $200 \mathrm{~g}$ of fruit in each bag.

The following chemical compounds were determined:

a. the content of total polyphenols by the spectrophotometric Folin-Ciocalteau method using a spectrophotometer UviLine 9400 at wave length $750 \mathrm{~nm}$ according to Sluis et al. (2002) and using catechin as a standard;

b. the total content of flavonoids by the spectrophotometric method using a spectrophotometer UviLine 9400 at wave length $510 \mathrm{~nm}$ according to Zhishen et al. (1999) and Eberhardt et al. (2000) and using catechin as a standard;

c. the total content of carotenoids by the spectrophotometric method using a spectrophotometer UviLine 9400 at wave length $451 \mathrm{~nm}$ according to Davis (1965) and Umiel and Gabelman (1971);

d. the content of ascorbic acid using 2.6-dichlorophenyloindophenol titrimetric method according to PN-A-04019(1998).

e. the antioxidant activity (AOA) by $\beta$-carotene bleaching method based on coupled oxidation of $\beta$-carotene and linoleic acid according to Emmons et al. (1999) and the antiradical activity (ARA) by 2,2-diphenyl-1-picrylhydrazyl $(\mathrm{DPPH} \bullet)$ free radical scavenging assay according to Brand-Williams et al. (1995) and Sánchez -Moreno et al. (2002).

Statistical calculations were performed using STATISTICA v. 10 (StatSoft 2011) as one-way analysis of variance separately for seasons and cultivars. The significant differences between means were determined at $p=0.05$ by Tukey's test. The results are expressed as the mean of three replicates $(n=3)$. The correlation coefficient $(r)$ was used to determine the relationship between polyphenol content and antioxidant and antiradical activity of stripped pepper fruit. 


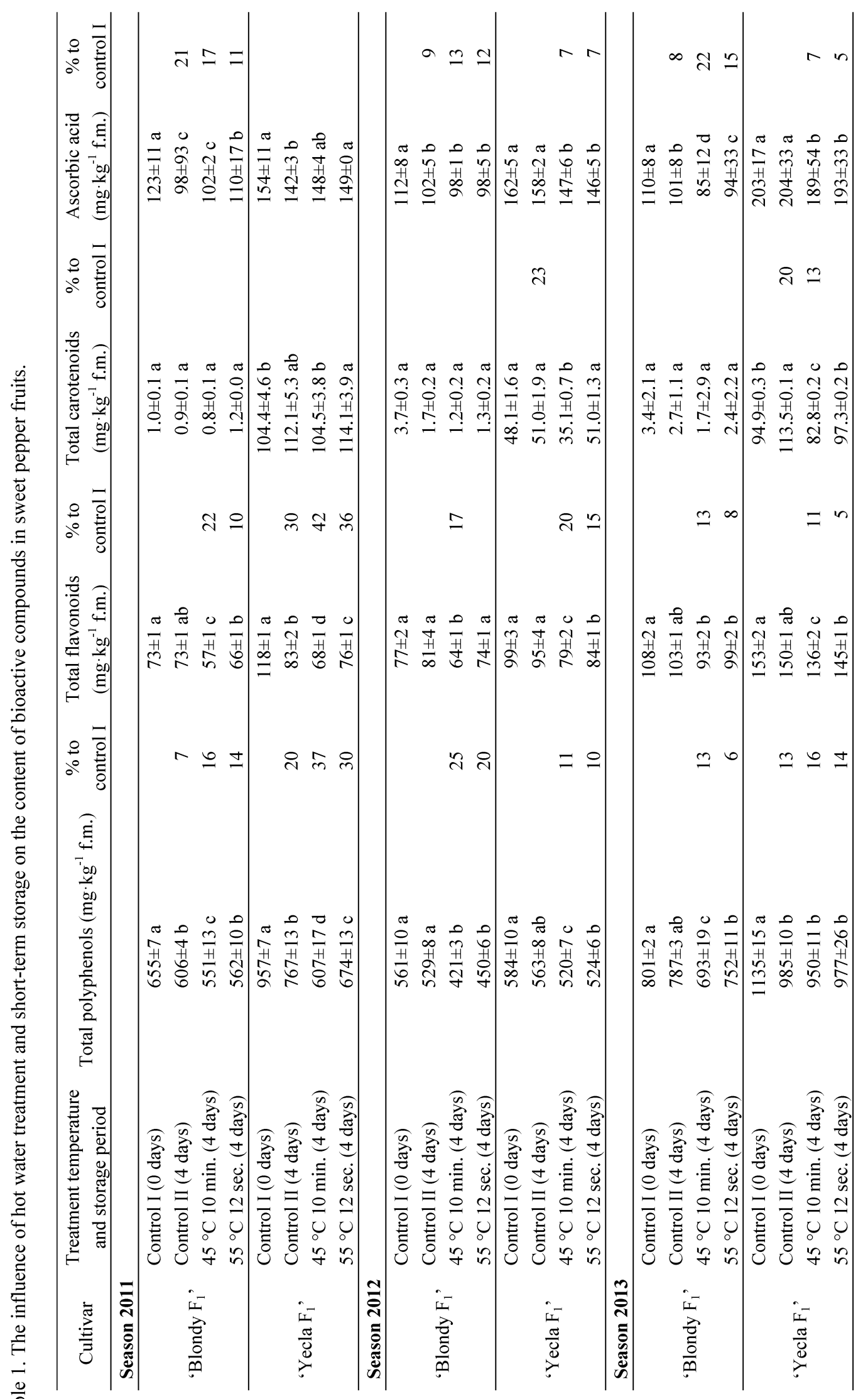




\section{RESULTS AND DISCUSSION}

Fresh fruit samples of two cultivars of sweet pepper differed at the start of experiment (Control I) for nearly all the studied traits, what was the result of genetic differences. The range of differences depended on the year. The values were higher in 2011 and 2013 than in 2012 (Table 1,2). The greatest differences were in carotenoid content (from about 17 to $100 x$ more in 'Yecla $F_{1}$ ' than 'Blondy $F_{1}$ '). Also, the growth season influenced values of all parameters at the start of experiment. It was the reason that statistical analyses were conducted for cultivars and seasons separately.

For most of the analyzed traits, the highest values were obtained in 2013. Thermal conditions for the growth of peppers during the growing season 2013 were appropriate for thermophilic plants, with an average temperature above $18^{\circ} \mathrm{C}$, from June to the end of August. In addition, a large number of sunshine hours compared to other years was noted. It is well known that not only the indigenous plant traits but also external factors, including weather conditions (temperature, rainfall, hours of sunshine) decide on the scope and shape of these changes (Buczkowska 1991; Gaye et al. 1992; Korzeniewska \& Niemirowicz-Szczyt 1997).

A higher content of bioactive compounds, as well as antioxidant and antiradical activity characterized the fruit of pepper 'Yecla $F_{1}$ ' than the fruits of 'Blondy $F_{1}$ ', regardless of the examined factors (Table 1,2).

Table 2. The influence of hot water treatment and short-term storage on the antioxidant (AOA) and antiradical activity (ARA) in pepper fruits (2011-2013)

\begin{tabular}{|c|c|c|c|c|c|}
\hline Cultivar & $\begin{array}{l}\text { Treatment temperature } \\
\text { and (storage period) }\end{array}$ & $\mathrm{AOA}(\%)$ & $\begin{array}{c}\% \text { to } \\
\text { Control I } \\
\end{array}$ & $\operatorname{ARA}(\%)$ & $\begin{array}{c}\% \text { to } \\
\text { Control I }\end{array}$ \\
\hline \multicolumn{6}{|l|}{ Season 2011} \\
\hline \multirow{4}{*}{ 'Blondy $\mathrm{F}_{1}$ ' } & Control I (0 days) & $32.3 \pm 2.4 \mathrm{a}$ & & $74.1 \pm 2.0 \mathrm{a}$ & \\
\hline & Control II (4 days) & $27.2 \pm 2.8 \mathrm{a}$ & & $64.2 \pm 1.2 \mathrm{~b}$ & 13 \\
\hline & $45^{\circ} \mathrm{C} 10 \mathrm{~min}$. (4 days) & $16.6 \pm 2.2 \mathrm{~b}$ & 49 & $49.5 \pm 1.1 \mathrm{c}$ & 49 \\
\hline & $55^{\circ} \mathrm{C} 12$ sec. (4 days) & $19.0 \pm 1.7 \mathrm{~b}$ & 41 & $67.7 \pm 5.3 \mathrm{ab}$ & \\
\hline \multirow{4}{*}{ 'Yecla $F_{1}$ ' } & Control I (0 days) & $61.4 \pm 0.7 \mathrm{a}$ & & $77.8 \pm 2.0 \mathrm{a}$ & \\
\hline & Control II (4 days) & $45.3 \pm 1.9 \mathrm{~b}$ & 26 & $55.6 \pm 1.2 \mathrm{~b}$ & 29 \\
\hline & $45^{\circ} \mathrm{C} 10 \mathrm{~min}$. (4 days) & $33.1 \pm 0.7 \mathrm{~d}$ & 46 & $38.9 \pm 2.9 \mathrm{c}$ & 50 \\
\hline & $55^{\circ} \mathrm{C} 12$ sec. $(4$ days $)$ & $39.6 \pm 0.3 \mathrm{c}$ & 36 & $49.3 \pm 2.5 \mathrm{~b}$ & 38 \\
\hline \multicolumn{6}{|l|}{ Season 2012} \\
\hline \multirow{4}{*}{ 'Blondy $\mathrm{F}_{1}$ ' } & Control I (0 days) & $41.1 \pm 1.6 \mathrm{a}$ & & $49.9 \pm 1.4 \mathrm{a}$ & \\
\hline & Control II (4 days) & $33.0 \pm 1.0 \mathrm{~b}$ & 20 & $38.8 \pm 1.0 \mathrm{~b}$ & 22 \\
\hline & $45^{\circ} \mathrm{C} 10$ min. (4 days) & $16.1 \pm 1.1 \mathrm{~d}$ & 61 & $31.7 \pm 1.5 \mathrm{c}$ & 36 \\
\hline & $55^{\circ} \mathrm{C} 12$ sec. (4 days) & $22.8 \pm 1.4 \mathrm{c}$ & 45 & $35.4 \pm 0.6 \mathrm{bc}$ & 29 \\
\hline \multirow{4}{*}{ 'Yecla F' } & Control I (0 days) & $43.7 \pm 1.7 \mathrm{a}$ & & $53.8 \pm 3.1 \mathrm{a}$ & \\
\hline & Control II (4 days) & $28.6 \pm 1.5 \mathrm{~b}$ & 35 & $44.7 \pm 1.4 \mathrm{~b}$ & 17 \\
\hline & $45^{\circ} \mathrm{C} 10 \mathrm{~min}$. (4 days) & $17.0 \pm 0.8 \mathrm{c}$ & 61 & $37.6 \pm 1.0 \mathrm{~b}$ & 30 \\
\hline & $55^{\circ} \mathrm{C} 12$ sec. (4 days) & $25.4 \pm 1.0 \mathrm{~b}$ & 58 & $39.1 \pm 1.0 \mathrm{~b}$ & 27 \\
\hline \multicolumn{6}{|l|}{ Season 2013} \\
\hline \multirow{4}{*}{ 'Blondy $\mathrm{F}_{1}$ ' } & Control I (0 days) & $36.8 \pm 0.4 \mathrm{a}$ & & $76.4 \pm 2.4 \mathrm{a}$ & \\
\hline & Control II (4 days) & $30.1 \pm 1.0 \mathrm{~b}$ & 18 & $64.7 \pm 2.7 \mathrm{~b}$ & 15 \\
\hline & $45^{\circ} \mathrm{C} 10 \mathrm{~min}$. (4 days) & $23.4 \pm 1.1 \mathrm{c}$ & 36 & $56.2 \pm 0.3 \mathrm{c}$ & 26 \\
\hline & $55^{\circ} \mathrm{C} 12$ sec. (4 days) & $25.1 \pm 0.7 \mathrm{~b}$ & 32 & $64.6 \pm 2.0 \mathrm{~b}$ & 15 \\
\hline \multirow{4}{*}{ 'Yecla F ' } & Control I (0 days) & $42.1 \pm 1.1 \mathrm{a}$ & & $90.2 \pm 1.5 \mathrm{a}$ & \multirow{4}{*}{9} \\
\hline & Control II (4 days) & $37.7 \pm 0.8 \mathrm{ab}$ & & $82.5 \pm 2.1 \mathrm{~b}$ & \\
\hline & $45^{\circ} \mathrm{C} 10 \mathrm{~min}$. (4 days) & $28.4 \pm 0.8 \mathrm{c}$ & 33 & $84.7 \pm 0.3 \mathrm{ab}$ & \\
\hline & $55^{\circ} \mathrm{C} 12$ sec. (4 days) & $32.1 \pm 1.1 \mathrm{~b}$ & 24 & $87.4 \pm 0.5 \mathrm{ab}$ & \\
\hline
\end{tabular}

Note: Means in the column for each cultivar and year separately marked with the same letter are not significantly different according to Tukey's test $(\mathrm{p}=0.05)$. 
According to Häkkinen \& Törrönen (2000); Howard et al. (2000); Wang and Lin (2000); Borowska (2003); Perucka et al. (2004); Ozgur et al. (2011), the composition and the content of bioactive compounds in the pepper fruit depend on the cultivar and maturity stage and are higher in the fully colored fruits. Also, the antioxidant and antiradical activities depend on the cultivar (Ghasemnezhad et al. 2011; Medina-Juárez et al. 2012; Campos et al. 2013; Ornelas-Paz et al. 2013; Shaha et al. 2013; Loizzo et al. 2015).

In our study, the storage of stripped pepper fruit for 4 days at $5{ }^{\circ} \mathrm{C}$ caused a decrease in the content of polyphenols by 2-7\% in 'Blondy $\mathrm{F}_{1}$ ' and $11-$ $20 \%$ in 'Yecla $F_{1}$ ', depending on the year. Total flavonoids and carotenoids contents were not affected by the storage. Ascorbic acid contents decreased in the result of storage by 8 to $21 \%$ in 'Blondy $F_{1}$ ' but not in 'Yecla $F_{1}$ '.

The treatment with water at $45^{\circ} \mathrm{C}$ for $10 \mathrm{~min}$. before storage decreased the content of polyphenols by $12-25 \%$ in 'Blondy $\mathrm{F}_{1}$ ' and by $11-37 \%$ in 'Yecla $\mathrm{F}_{1}$ '. Also, the total flavonoids content decreased by this treatment by $13-22 \%$ in 'Blondy $\mathrm{F}_{1}$ ' and $11-$ $42 \%$ in 'Yecla $\mathrm{F}_{1}$ '. Carotenoids content was not affected in 'Blondy $F_{1}$ ' and in 'Yecla $F_{1}$ ' only in 2012 and 2013 by 13 and $23 \%$. Ascorbic acid contents decreased in 'Blondy $F_{1}$ ' by $13-22 \%$ and in 'Yecla $\mathrm{F}_{1}$ ' only in 2012 and 2013 by $7 \%$.

The treatment with water at $55^{\circ} \mathrm{C}$ for $12 \mathrm{sec}$. before storage decreased the total polyphenols contents of 'Blondy $\mathrm{F}_{1}$ ' by 6-20\% and in 'Yecla $\mathrm{F}_{1}$ ' by $10-30 \%$. Total flavonoids in 'Blondy $\mathrm{F}_{1}$ ' decreased by $8-10 \%$ only in 2011 and 2013 , and in 'Yecla $F_{1}$ ' by $5-36 \%$. The carotenoid content was not affected and the ascorbic acid content decreased by $11-15 \%$ in 'Blondy $F_{1}$ ' and by $5-7 \%$ in 'Yecla $F_{1}$ ' in 2012 and 2013.

In our study, antioxidant and antiradical activity of pepper fruit strips was affected by the 4-day storage at $5{ }^{\circ} \mathrm{C}$. $\mathrm{AOA}$ in 'Blondy $\mathrm{F}_{1}$ ' was lower in 2012 and 2013 by 20 and $18 \%$, and in 'Yecla $\mathrm{F}_{1}$ ' by 26-35\%. ARA was lower by $13-22 \%$ in 'Blondy $\mathrm{F}_{1}$ ' and by $9-29 \%$ in 'Yecla $\mathrm{F}_{1}$ '. The treatment with water at $45^{\circ} \mathrm{C}$ for 10 min decreased AOA by 36$61 \%$ in 'Blondy $\mathrm{F}_{1}$ ' and by $30-50 \%$ in 'Yecla $\mathrm{F}_{1}$ ' (only in 2011 and 2012). The treatment with water at $55^{\circ} \mathrm{C}$ for $12 \mathrm{sec}$. decreased AOA by $32-45 \%$ in 'Blondy $\mathrm{F}_{1}$ ' and by $24-58 \%$ in 'Yecla $\mathrm{F}_{1}$ '. ARA was not affected in 'Blondy $F_{1}$ ' in 2011 and in 2012 and 2013 decreased by 29 and $15 \%$. In 'Yecla F', ARA was affected in 2011 and 2012 by 28 and $37 \%$ respectively (Table 1,2).

Comparing the two treatments with hot water indicates that in almost every case, the greater reduction of contents and activities was recorded using water at $45^{\circ} \mathrm{C}$ for $10 \mathrm{~min}$ than at $56^{\circ} \mathrm{C}$ for $12 \mathrm{sec}$.

There are several papers concerning short-storage of fresh cut vegetables. Grzegorzewska (2014) found a slight decrease in storage quality in the fresh cut peppers, stored for 4 days at $5^{\circ} \mathrm{C}$, both treated and untreated with hot water but its commercial value was still high. The best quality was observed when the fresh cut pepper fruit were treated with water at $55^{\circ} \mathrm{C}$ for $12 \mathrm{sec}$. in comparison with treatments at $45^{\circ} \mathrm{C}$ for $10 \mathrm{~min}, 50{ }^{\circ} \mathrm{C}$ for $5 \mathrm{~min}$. and $53{ }^{\circ} \mathrm{C}$ for $3 \mathrm{~min}$. This suggests that slight decrease in the quality of storage could have an impact on reducing the content of bioactive compounds and antioxidant activity.

Table 3. The linear correlation coefficient (r) characterizing the relationship between the content of total polyphenols $\left(\mathrm{mg} \cdot \mathrm{kg}^{-1}\right.$ f.m.) and antioxidant and antiradical activity $(\%)$ of pepper fruits treated with hot water and stored for 4 days (2011-2013)

\begin{tabular}{|c|c|c|c|c|c|c|}
\hline \multirow{3}{*}{ Cultivar } & \multicolumn{3}{|c|}{$\begin{array}{c}\text { polyphenols/AOA } \\
\text { correlation coefficient }\end{array}$} & \multicolumn{3}{|c|}{$\begin{array}{c}\text { polyphenols/ARA } \\
\text { correlation coefficient }\end{array}$} \\
\hline & \multicolumn{6}{|c|}{ Season } \\
\hline & 2011 & 2012 & 2013 & 2011 & 2012 & 2013 \\
\hline 'Blondy $F_{1}$ ' & $0.592 * *$ & $0.937 * * *$ & $0.819 * * *$ & $0.866 * * *$ & $0.817 * * *$ & $0.828 * * *$ \\
\hline 'Yecla $F_{1}$ ' & $0.983^{* * *}$ & $0.954 * * *$ & $0.781 * * *$ & $0.979 * * *$ & $0.862 * * *$ & $0.614 * *$ \\
\hline
\end{tabular}


Table 4. The linear correlation coefficient (r) characterizing the influence of the short-term storage on the relationship between the content of total polyphenols ( $\mathrm{mg} \cdot \mathrm{kg}^{-1} \mathrm{f} . \mathrm{m}$.) and antioxidant and antiradical activity (\%) of pepper fruits (2011-2013)

\begin{tabular}{ccccccc}
\hline \multirow{2}{*}{$\begin{array}{c}\text { Storage } \\
\text { (days) }\end{array}$} & \multicolumn{3}{c}{$\begin{array}{c}\text { polyphenols/AOA } \\
\text { correlation coefficient }\end{array}$} & \multicolumn{3}{c}{$\begin{array}{c}\text { polyphenols/ARA } \\
\text { correlation coefficient }\end{array}$} \\
\cline { 2 - 7 } & \multicolumn{3}{c}{ Season } \\
\cline { 2 - 7 } & 2011 & 2012 & 2013 & 2011 & 2012 & 2013 \\
\hline 0 & $0.978^{* * *}$ & 0.142 & $0.881^{* * *}$ & $0.680^{* *}$ & 0.148 & $0.918^{* * *}$ \\
\hline 4 & $0.789 * * *$ & $0.634^{* *}$ & $0.789 * * *$ & -0.039 & $0.850^{* * *}$ & $0.940^{* * *}$ \\
\hline
\end{tabular}

$* * * \mathrm{p} \leq 0.001, * * \mathrm{p} \leq 0.01$

Table 5. The linear correlation coefficient (r) characterizing the influence of hot water treatment on the relationship between the content of total polyphenols ( $\mathrm{mg} \cdot \mathrm{kg}^{-1} \mathrm{f} . \mathrm{m}$.) and antioxidant and antiradical activity (\%) of pepper fruits (2011-2013)

\begin{tabular}{|c|c|c|c|c|c|c|}
\hline \multirow{3}{*}{$\begin{array}{l}\text { Temp. } \\
\text { treatment } \\
\left({ }^{\circ} \mathrm{C}\right)\end{array}$} & \multicolumn{3}{|c|}{$\begin{array}{c}\text { polyphenols/AOA } \\
\text { correlation coefficient }\end{array}$} & \multicolumn{3}{|c|}{$\begin{array}{c}\text { polyphenols/ARA } \\
\text { correlation coefficient }\end{array}$} \\
\hline & \multicolumn{6}{|c|}{ Season } \\
\hline & 2011 & 2012 & 2013 & 2011 & 2012 & 2013 \\
\hline Control I & $0.968 * * *$ & 0.452 & $0.797 * * *$ & 0.367 & $0.702 * *$ & $0.844 * * *$ \\
\hline 45 & $0.963 * * *$ & $0.820 * * *$ & $0.711^{* * *}$ & $0.709 * *$ & $0.878^{* * * *}$ & $0.897 * * *$ \\
\hline 55 & $0.914 * * *$ & $0.867 * * *$ & $0.721 * * *$ & 0.460 & $0.849 * * *$ & $0.880^{* * *}$ \\
\hline
\end{tabular}

$* * * \mathrm{p} \leq 0.001, * * \mathrm{p} \leq 0.01$

Barbagallo et al. (2012) stated that during the storage of fresh cut yellow and red fruit of pepper for fourteen days at $4{ }^{\circ} \mathrm{C}$ the content of ascorbic acid was reduced, but the polyphenols content increased. On the other hand, Michalczyk and Macura (2008) in their study during the storage of lamb's lettuce, arugula and iceberg lettuce for 9 days at 0 and $6{ }^{\circ} \mathrm{C}$ observed a decrease in the content of polyphenols, carotenoids and ascorbic acid.

A significant correlation was found between the content of total polyphenols and antioxidant and antiradical activity of the two cultivars of sweet peppers, regardless of the temperature treatment with hot water and period of short-term storage, in each experimental season (Table 3 ). A positive correlation between polyphenol content and AOA and ARA activity in both pepper cultivars have also been found, depending on the period of short-term storage and the temperature treatment with hot water, the differences were significant, although not in every year (Table 4,5 ).

\section{CONCLUSIONS}

1. The storage of fresh cut sweet pepper fruit 'Blondy $\mathrm{F}_{1}$ ' and 'Yecla $\mathrm{F}_{1}$ ' for 4 days at $5{ }^{\circ} \mathrm{C}$ diminished the contents of bioactive substances and antioxidant and antiradical activity, but the reduction was not significant in each of the seasons.

2. The treatment with hot water $\left(45^{\circ} \mathrm{C}\right.$ for $10 \mathrm{~min}$., $55^{\circ} \mathrm{C}$ for $12 \mathrm{sec}$.) preceding the short-term storage of fresh cut pepper fruit 'Blondy $F_{1}$ ' and 'Yecla $F_{1}$ ' had a significant impact on reducing the content of bioactive compounds and antioxidant properties. Treatment with water at $55^{\circ} \mathrm{C}$ for $12 \mathrm{sec}$. caused lower losses in content of bioactive compounds and antioxidant and antiradical activity than the treatment with water at $45^{\circ} \mathrm{C}$ for $10 \mathrm{~min}$.

3. The antioxidant and antiradical activity was significantly dependent on the content of total polyphenols in fruit of pepper 'Blondy $\mathrm{F}_{1}$ ' and 
'Yecla $\mathrm{F}_{1}$ ' after the treatment with water $\left(45^{\circ} \mathrm{C}-\right.$ $10 \mathrm{~min}$. or $55^{\circ} \mathrm{C}-12 \mathrm{sec}$.) and the short term storage, in each experimental season.

\section{REFERENCES}

Barbagallo R.N., Chisari M., Patané C. 2012. Polyphenol oxidase, total phenolics and ascorbic acid changes during storage of minimally processed 'California Wonder' and 'Quadrato d'Asti' sweet peppers. LWT - Food Science and Technology 49: 192-196. DOI: 10.1016/j.lwt.2012.06.023.

Borowska J. 2003. Owoce i warzywa jako źródło naturalnych przeciwutleniaczy [2]. Przemysł Fermentacyjny 6: 29-30. [in Polish]

Brand-Williams W., Cuvelier M.E., Berset C. 1995. Use of a free radical method to evaluate antioxidant activity. Lebensmittel-Wissenschaft \& Technologie 28: 25-30. DOI: 10.1016/S0023-6438(95)80008-5.

Buczkowska H. 1991. Plonowanie papryki słodkiej (Capsicum annuum L.) w uprawie polowej na tle warunków pogodowych. Annales Universitatis Mariae Curie-Skłodowska, sectio E 46(27): 211 220. [in Polish]

Campos M.R.S., Gómez K.R., Ordoñez Y.M., Ancona D.B. 2013. Polyphenols, ascorbic acid and carotenoids contents and antioxidant properties of habanero pepper (Capsicum chinense) fruit. Food and Nutrition Sciences 4: 47-54. DOI: 10.4236/fns.2013.48A006.

Eberhardt M.V., Lee C.Y., Liu R.H. 2000. Antioxidant activity of fresh apples. Nature 405: 903-904. DOI: 10.1038/35016151.

Emmons C.L., Peterson D.M., Paul G.L. 1999. Antioxidant capacity of oat (Avena sativa L.) extracts. 2. In vitro antioxidant activity and contents of phenolic and tocol antioxidants. Journal of Agricultural and Food Chemistry 47: 4894-4898. DOI: 10.1021/jf990530i.

Fallik E. 2004. Prestorage hot water treatments (immersion, rinsing and brushing). Postharvest Biology and Technology 32(2): 125-134. DOI: 10.1016/j.postharvbio.2003.10.005.

Fallik E., Grinberg S., Alkalai S., Yekutieli O., Wiseblum A., Regev R. et al. 1999. A unique rapid hot water treatment to improve storage quality of sweet pepper. Postharvest Biology and Technology 15(1): 25-32. DOI: 10.1016/S0925-5214(98)00066-0.

Favell D.J. 1998. A comparison of the vitamin C content of fresh and frozen vegetables. Food Chemistry 62(1): 59-64. DOI: 10.1016/S0308-8146(97)00165-9.
Ferguson I.B., Ben-Yehoshua S., Mitcham E.J., McDonald R.E., Lurie S. 2000. Postharvest heat treatments: introduction and workshop summary. Postharvest Biology and Technology 21(1): 1-6. DOI: 10.1016/S0925-5214(00)00160-5.

Gaye M.M., Jolliffe P.A., Maurer A.R. 1992. Row cover and population density effects on yield of bell peppers in south coastal British Columbia. Canadian Journal of Plant Science 72: 901-909. DOI: 10.4141/cjps92-113.

Ghasemnezhad M., Sherafati M., Payvast G.A. 2011. Variation in phenolic compounds, ascorbic acid and antioxidant activity of five coloured bell pepper (Capsicum annum) fruits at two different harvest times. Journal of Functional Foods 3: 44-49. DOI: 10.1016/j.jff.2011.02.002.

Grzegorzewska M. 2014. The effect of hot water treatment and type of unit packaging on durability of fresh-cut pepper during short storage. Zeszyty Naukowe Instytutu Ogrodnictwa 22: 19-29. [in Polish with English abstract]

Häkkinen S.H., Törrönen A.R. 2000. Content of flavonols and selected phenolic acids in strawberries and Vaccinium species: influence of cultivar, cultivation site and technique. Food Research International 33: 517-524. DOI: 10.1016/S09639969(00)00086-7.

Howard L.R., Talcott S.T., Brens C.H., Villalon B. 2000. Changes in phytochemical and antioxidant activity of selected pepper cultivars (Capsicum species) as influenced by maturity. Journal of Agricultural and Food Chemistry 48: 1713-1720. DOI: 10.1021/jf990916t.

Korzeniewska A., Niemirowicz-Szczytt K. 1997. Nowe mieszańce papryki słodkiej do uprawy w polu. VII Ogólnopolski Zjazd Hodowców Roślin Ogrodniczych, Szczecin, pp. 211-213. [in Polish]

Leszczyńska-Fik A., Fik M. 2003. Kiełki roślinne. Jakość mikrobiologiczna skiełkowanych nasion. Przemysł Fermentacyjny i Owocowo-Warzywny 12: 29-31. [in Polish]

Loizzo M.R., Pugliese A., Bonesi M., Menichini F., Tundis R. 2015. Evaluation of chemical profile and antioxidant activity of twenty cultivars from Capsicum annuum, Capsicum baccatum, Capsicum chacoense and Capsicum chinense: A comparison between fresh and processed peppers. LWT - Food Science and Technology 64: 623-631. DOI: 10.1016/j.lwt.2015.06.042.

Lurie S. 1998. Postharvest heat treatments. Postharvest Biology and Technology 14(3): 257-269. DOI: 10.1016/s0925-5214(98)00045-3. 
Medina-Juárez L.Á., Molina-Quijada D.M.A., Del ToroSánchez C.L., González-Aguilar G.A., GámezMeza N. 2012. Antioxidant activity of peppers (Capsicum annuum L.) extracts and characterization of their phenolic constituents. Interciencia 37(8): 588-593.

Michalczyk M., Macura R. 2008. Effect of storage conditions on the quality of some selected low processed vegetable products available in the markets. Żywność Nauka Technologia Jakość 3(58): 96107. [in Polish with English abstract]

Ornelas-Paz J. de J., Cira-Chávez L.A., Gardea-Béjar A.A., Guevara-Arauza J.C., Sepúlveda D.R., Reyes-Hernández J., Ruiz-Cruz S. 2013. Effect of heat treatment on the content of some bioactive compounds and free radical-scavenging activity in pungent and non-pungent peppers. Food Research International 50: 519-525. DOI: 10.1016/j.foodres.2011.01.006.

Ozgur M., Ozcan T., Akpinar-Bayizit A., Yilmaz-Ersan L. 2011. Functional compounds and antioxidant properties of dried green and red peppers. African Journal of Agricultural Research 6(25): 56385644. DOI: 10.5897/AJAR11.709.

Perucka I. 2004. Changes of carotenoid contents during ripening of pepper fruits and ethephon treatment. Acta Scientiarum Polonorum, Technologia Alimentaria 3(1): 85-92. [in Polish with English abstract]

PN-A-04019:1998. Produkty spożywcze. Oznaczanie zawartości witaminy C. sklep.pkn.pl/pn-a-040191998p.html [in Polish]

Radziejewska-Kubzdela E., Czapski J., Czaczyk K. 2007. The effect of packaging conditions on the quality of minimally processed celeriac flakes. Food Control 18: 1191-1197. DOI: 10.1016/j.foodcont.2006.07.019.

Saltveit M.E. 1998. Heat-shock and fresh cut lettuce. Perishables Handling Quarterly 95: 5-6.

Sánchez-Moreno C. 2002. Methods used to evaluate the free radical scavenging activity in foods and biological systems. Food Science and Technology International 8: 121-137. DOI: $10.1106 / 108201302026770$.
Shaha R.K., Rahman S., Asrul A. 2013. Bioactive compounds in chilli peppers (Capsicum annuum L.) at various ripening (green, yellow and red) stages. Annals of Biological Research 4(8): 27-34.

van der Sluis A., Dekker M., Skrede G., Jongen W.M.F. 2002. Activity and concentration of polyphenolic antioxidants in apple juice. 1. Effect of existing production methods. Journal of Agricultural and Food Chemistry 50(25): 7211-7214. DOI: $10.1021 / \mathrm{jf020115h}$.

Umiel N., Gabelman W.H. 1971. Analytical procedures for detecting carotenoids of carrot (Daucus carota L.) roots and tomato (Lycopersicon esculentum) fruits. Journal of the American Society for Horticultural Science 96: 702-704.

Varoquaux P., Wiley R.C. 1994. Biological and biochemical changes in minimally processed refrigerated fruits and vegetables. In: Wiley R.C. (Ed.), Minimally processed refrigerated fruits and vegetables. Chapman \& Hall Inc., pp. 226-268. DOI: 10.1007/978-1-4615-2393-2_6.

Vlachonasios K.E., Kadyrzhanova D.K., Dilley D.R. 2001. Heat treatment prevents chilling injury of tomato (Lycopersicon esculentum) fruits: heat shock genes and heat shock proteins in the resistance of tomato fruit to low temperatures. Acta Horticulturae 533: 543-547. DOI: 10.17660/ActaHortic.2001.553.126.

Wang S.Y., Lin H.S. 2000. Antioxidant activity in fruits and leaves of blackberry, raspberry, and strawberry varies with cultivar and developmental stage. Journal of Agricultural and Food Chemistry 48: 140146. DOI: $10.1021 /$ jf9908345.

Yildiz F. 1994. Initial preparation, handling, and distribution of minimally processed refrigerated fruits and vegetables. In: Wiley R.C. (Ed.), Minimally processed refrigerated fruits and vegetables. Chapman \& Hall Inc., pp. 15-65. DOI: 10.1007/978-14615-2393-2_2.

Zhishen J., Mengcheng T., Jianming W. 1999. The determination of flavonoid contents in mulberry and their scavenging effects on superoxide radicals. Food Chemistry 64: 555-559. DOI: 10.1016/S0308-8146(98)00102-2. 